\title{
INNOVATIONS THROUGH VERTICAL DYAD LINKAGE MODEL
}

DOI: 10.12776/QIP.V18I2.368

\author{
PAVEL MIKUŠ
}

Received 27 August 2014, Revised 16 October 2014, Accepted 10 November 2014

\section{INTRODUCTION}

For the organizations it's more and more difficult to survive in the fast changing world in their environment. They apply more and more methods which would enable them to control these changes. In the present climate of entrepreneurs' uncertainty, the ability to react on changes it's a fundamental precondition for survival of each organization. As well as the ability to align managers with staff quickly, this is crucial. Taking into consideration the global busines enviroment, the changes inside of organization are unavoidable process. Although it's difficult to execute them due to mutual dependence of stakeholders, organization and used technology. There are in general two crucial aspects to achieve the required business results - the change of the employees behaviour and their active involvement. The way how to lead the organization through innovation process is in principle well known and seemingly simple - to adjust an enviroment within the organization for cooperation of people, processes and technology alignment with active leadership from management side and applying efficient business strategy.

\section{CHANGES IN ORGANIZATION}

Changes are the result of dynamic character in modern world. No organization is immune against them, any change is the final one. The new situation brings new problems and these need a solution. These are usually a subject for next change and therefore the changes are permanent part of the business environment nowadays. Efficient managers need to recognize the change management as an integral part of their duties, not just marginal one (Mikuš, 2010).

Change would be considered like any activity within organization related to people, organizational structure or technology and make towards to improvement of activities, position of organization in the business competion with the aim to 
meet growing needs of the customers for their cheerful life (Droppa, Mikuš and Lysá, 2004).

If there are no changes in the organization, i.e. changes related to people, structure or technology, the work of managers will be relatively simple. The planning will be easy, as tomorrow won't be different from today. Decision making will be straight forward, as the outputs of each alternative will be considerably predictable. To make the work of managers simpler, the competition won't come up with new products, customers won't ask for improved products and services and government won't change legislation and restrictions. But such world doesn't exist. Change is a reality of organization (Robbins and Coutler, 2004).

\section{CHANGE HOLDERS}

Top and middle management are the key players of the overall organizational change execution and should lead the organization through all phases. Top managers are responsible for defining the strategy, its realization and managing of transformation process. They are the initiators of change, determine its content and direction, decide on procedures of its realization and authorize teams and employees who are responsible for partial steps leading to change (Bedrnová and Nový, 1998).

To execute a substantial system changes within the organization there is usually appointed a working group which consists from internal as well as external experts. They all focusing on given problem and closely cooperate with company, or person, who set this business case.

All involved parties could have a different view on how to solve the problem. This status couldn't be necessarily bad. In such circumstances it's important to find a compromise solution respecting all these opinions but at the same time the results should bring the innovation.

Due to detachment of external consultant this has a different, uninfluenced view about the change management in organization. On the othe hand the internal manager who is more involved and understands the whole complexity is coming with more tentative suggestions. He knows the details about the financial possibilities of the company, employees and possibilities to manage technological procedures. He takes into consideration internal environment of the company, where and how could occur the consequences of the system change (Droppa, Mikuš and Lysá, 2004).

\section{BASES OF THE VERTICAL DYAD LINKAGE (VDL) MODEL}

Theory of VDL (Vertical Dyad Linkage) model - vertical pair of relationships is applied in the area such as organizational behavior, management, leadership and 
managerial decision making. Regarding the VDL mode concept its authors Dansereau, Graen and Haga worked on the concept based on their opinion that managers don't cooperate with their employees identically because they have limited time and resources. The theory has been established on assumption that managers divide their employees into two different groups, called "in-group" and "out-group". VDL is a traditional leadership approach that is based on the individual exchange relationship between leader and follower. Under this model, leaders develop different relationships with followers. With some followers, there is a relationship of leadership exchanges, where the influence over the follower stems from the perception of the existence of a partnership; with other followers, there is a relationship of supervisory exchanges, where the influence over the follower is primarily based on authority (Dansereau, 1995). This leadership approach fits within the individual-based leadership category because it refutes the assumption that leaders lead all followers uniformly.

The VDL model "describes the process by which a leader and a member develop various behavioural interdependencies between their respective roles" (Graen and Schiemann, 1978). Empirically, this model is tested using the variable negotiating latitude, which illustrates the extent to which the follower perceives the relationship with the leader as one characterized by interpersonal exchange at one extreme and by contractual obligations at the other extreme, or else falling somewhere in the middle of the spectrum (Dansereau, 1995; Liden and Graen, 1980). The negotiating latitude variable taps into specific aspects of the relationship, including the leader's willingness to evolve change in the follower's job, use his or her power to help the follower complete work, and bail out" the follower at the leader's expense.

In-group is characterized by a high quality relationship between superordinate and subordinate. Employees in this group are "close" to manager or are "manager's favorite", in terms of quality and professionalism. These employees are suitable for performing the required innovation, meet requested criteria. The researches show, that in this group is between super and sub ordinate the mutual confidence, positive support, open communication, high degree of independence, satisfaction and loyalty.

On the other hand the out-group is a social unit or group of people that an individual neither belongs to nor identifies with. The construction and maintenance of boundaries (physical or symbolic) are the primary ways by which groups establish what it means to be "in" and, by contrast, what it means to be "out." The basis of in-group identity, then, is socially constructed through symbolic markers (boundaries) such as narratives, creeds, rituals, and social practices. Moreover, sociologists view such boundaries along a continuum of permeability (open) and impermeability (closed), which influences group member entrance and exit processes. In-group identity, in other words, is always an ongoing achievement in which group boundaries are collectively generated, affirmed. 
In the "out-group" there are employees with lower quality in terms of working relationship with their superordinate, characterized by limited confidence, support and appreciation, evaluation and opportunities (Majtán, 2012, p. 150).

Each employee of the organization is actually a different individuality who could be characterized by a set of knowledge, abilities, skills, habits but also attitudes, opinions and values. As organizations associate different people a broad palette of potential is created which is able to contribute by its variability to the fulfillment of organizations targets (Holková and Horňák, 2003).

\section{ANALYSIS OF THE NEED OF INNOVATION}

The aim is to analyze the need for innovation in a company and with the help of VDL model select suitable employees who will participate in the process of innovation. For target realization, a method of situational analysis, VDLand analysis of performances/outputs were selected. The aim of the situational analysis was to find out how the goods are prepared in the company LC SA a.s. and if the innovation is needed. For the implementation of potential innovation, itis necessary to create a team of people who will participate in it. To divide people into groups, a VDL will be used. To be able to set up this model, we need to get data on functional scope of employment of individual employees and their qualities. We will get information about qualities of each employee based on evaluation of managers in accordance with individual stages of management. Managers will be evaluating employees based on specified criteria. Each employee will be evaluated in the range of 1 to 5 , while 5 will be the highest and 1 the lowest evaluation.

The research was done in a company LC SA a. s. The subject of the research was to analyze the state of the employee's potential, assignment of evaluation criteria and through the VDL model select those, who will show the necessary potential for the implementation of the process of innovation in the company. The subject of research is company LC SA a.s., established in February 2011 by transfer of rights and obligations from wholesale store.

Company LC SA a.s. was founded in compliance with $\$ 154$ section 3 of the Business Register by establishment agreement, written in a form of notary memorandum, on 3.12.2010, as closed corporation.

Scope of business:

- Purchase of goods for the purpose of their sale to final consumer (retail trade) or to other trade conductor (wholesale trade)

- storage

- cargo transport by vehicles with total weight up to $3.5 \mathrm{t}$ incl. trailer

- packing and handling of goods

- mediation/agent activity in the field of services

- mediation/agent activity in the field of commerce. 


\section{SITUATIONAL ANALYSIS OF THE NEED OF INNOVATION}

The outcome of the situational analysis is statement, that it is necessary to deal with situation in warehouse no. 2 and warehouse no. 3 , and not only concerning the warehouse capacity, but also the productivity of the employees.

Among internal factors supporting the change are: insufficient warehouse capacity, insufficient space for handling, time for goods preparation and cas fortuits.

Among external factors influencing the given situation are: increased number of items in the assortment group no. 2 and no. 3, growing number of claims from customers due to incorrect goods hand over.

During the three years of observation, problem of the size of warehouse, in terms of constant increased number of items, was not solved. It's necessary to make a change that would lead to improvement of given state.

By performing the situation analysis we came to a conclusion, that due to constant expansion of range of goods, organization doesn't have sufficient storage facilities. It is necessary to solve this alarming situation by the change of range of storage facilities, specifically by building new storage premises.

For the realization of innovative change, itis necessary to set up a group of employees, who will participate in this innovation, evaluate the financial state of the organization and suggest innovation process policy for the preparation of goods before their distribution.

\section{VDL MODEL OF LC SA A. S.}

Currently, there are 60 employees working for LC SA a.s. To set up a VDL model, we have put together information on functional scope of employment of individual employees. All managers on different stages of management took part in the evaluation. Before setting up the model, we have defined the criteria for the evaluation of quality of relationship between superordinate and subordinates. Employee, participating in innovation realization, needs to meet these criteria. Managers have used the following criteria for evaluation:

- expertise,

- hard working,

- reliability,

- personality traits,

- ability to work in a group,

- skills for the need of change (ability, skillfulness, acquired skills to perform given activity correctly, as fast as possible and effortlessly).

Individual criteria were evaluated in a range from 1 to 5 , while value 5 represents the highest rate of quality which meets our expectations, value 4 represents rate 
that meets our expectations only by one degree less, value 3 is a threshold limit of criteria and values 2 and 1 represent insufficient rate of quality.

The sum of values shows whether the employee will be integrated into in-group or into out-group. Employees who will gain less than 20 points will be integrated into out-group. Employees, who will gain more than 20 points will be integrated into in-group. This evaluation shows a rate how the manager and subordinate are seen with regards to their work and personality traits.

For the implementation of innovation in the process of goods preparation before their distribution in the warehouse no. 2 and warehouse no. 3, employees of warehouse no. 1 and employees of warehouse no. 4, employees of claims and packages warehouses, employees of branch, drivers and employees of other activities were automatically eliminated from analysis, based on functional scopes of their employment and functional classification, as the given problem does not concern them.

\section{a) Analysis of evaluation criteria of the relationship director - manager (Tab. 1)}

The aim was to find out the level of cooperation of director of LC SA a. s. and managers on the middle stage of management through qualitative criteria.

Table 1 - Evaluation of criteria of relationship by director-manager LC SA a. s.

\begin{tabular}{|c|c|c|c|c|c|c|c|c|}
\hline $\begin{array}{l}\text { Criterion } \\
\text { Employee } \\
\text { identification }\end{array}$ & 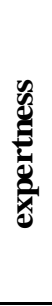 & 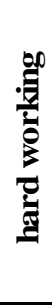 & 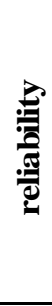 & 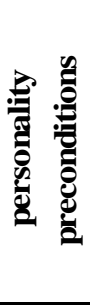 & 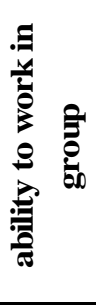 & 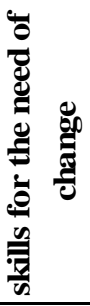 & 总 & Result \\
\hline M1 & 5 & 5 & 5 & 5 & 5 & 5 & 30 & IN \\
\hline M2 & 5 & 4 & 4 & 2 & 2 & 4 & 21 & IN \\
\hline M3 & 5 & 5 & 4 & 3 & 2 & 5 & 24 & IN \\
\hline M4 & 5 & 5 & 5 & 5 & 3 & 4 & 27 & IN \\
\hline M5 & 5 & 5 & 5 & 5 & 4 & 5 & 29 & IN \\
\hline
\end{tabular}

The table shows that all managers on the middle management level gained evaluation higher than 20 points. We can say that relationship between director and his subordinates on the middle stage of management is characterized as highly superior. The director highly evaluated expertise, hard working and reliability of all managers on the middle stage of management. One manager was evaluated that his personality traits are insufficient, one manager gained threshold limit in evaluation of this criterion.

Two of the managers gained excellent evaluation criteria of the ability to work in group, two managers gained threshold limits and one manager didn't meet 
preconditions to work in group. In conclusion the director has stated that all employees had skills for change execution.

Total evaluation classified all managers of the middle stage of management into in-group.

b) Analysis of criteria evaluation of the relationship of Head of economic department with subordinates through qualitative criteria. (Tab. 2)

Table 2 - Evaluation of criteria by Head of financial department

\begin{tabular}{|c|c|c|c|c|c|c|c|c|}
\hline $\begin{array}{l}\text { Criterion } \\
\begin{array}{l}\text { Employee } \\
\text { identification }\end{array}\end{array}$ & 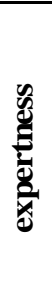 & 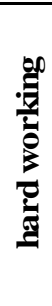 & 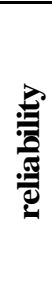 & 电 & 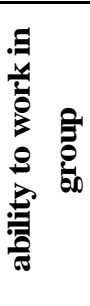 & 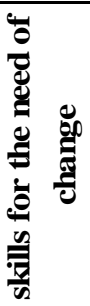 & 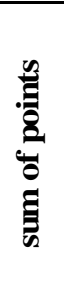 & Result \\
\hline U1 & 5 & 5 & 5 & 5 & 5 & 4 & 29 & IN \\
\hline U2 & 4 & 2 & 3 & 3 & 4 & 3 & 19 & OUT \\
\hline U3 & 5 & 5 & 4 & 4 & 5 & 4 & 27 & IN \\
\hline U4 & 5 & 5 & 5 & 5 & 5 & 5 & 30 & IN \\
\hline
\end{tabular}

The table shows that all employees of financial department gained higher evaluation than 20 points. There was just one exception, the employee who was evaluated by her superior as less hard working, less reliable and mostly as having lower skill potential for performance of planned change. We can say that the head of economic department considers her cooperation with subordinates as high quality cooperation. Besides one employee all others were evaluated as highly qualified and hard working. Employees are able to work in group, thanks to suitable personality traits. Almost all employees have skills which are necessary for the implementation of change. Total point evaluation classified three employees into in-group.

Table 3 - Evaluation of criteria by Head of sales department

\begin{tabular}{|c|c|c|c|c|c|c|c|c|}
\hline \begin{tabular}{|l|} 
Employee \\
identification
\end{tabular} & 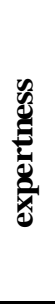 & 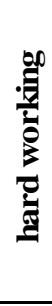 & 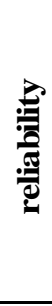 & 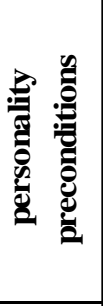 & 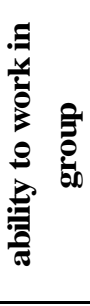 & 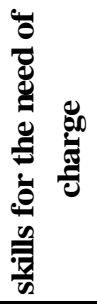 & 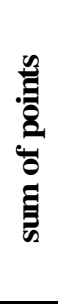 & Result \\
\hline O1 & 5 & 3 & 4 & 4 & 3 & 2 & 21 & IN \\
\hline $\mathbf{O 2}$ & 5 & 5 & 5 & 5 & 5 & 5 & 30 & IN \\
\hline $\mathbf{O 3}$ & 4 & 4 & 3 & 1 & 1 & 1 & 14 & OUT \\
\hline O4 & 4 & 3 & 3 & 2 & 2 & 1 & 15 & OUT \\
\hline
\end{tabular}




\section{c) Analysis of criteria evaluation of the relationship of Head of sales department with subordinates through qualitative criteria (Tab. 3).}

The table shows that two employees gained evaluation higher than 20 points and two employees gained evaluation lower than 20 points. The head of sales department highly evaluates expertise and hard working of her employees. Two employees were highly evaluated due to their reliability, two employees gained marginal limit. Only two employees met expectation in terms of personality performance. Only one employee gained the highest evaluation in the criterion of the ability to work in a group. Two employees were ranked in this category with insufficient evaluation. One employee reached marginal limit. From the above mentioned it is clear that head of sales department evaluates positively the cooperation only with two employees.

The total evaluation classified two employees into in-group and two into outgroup.

\section{d) Analysis of evaluation of criteria of the relationship of Head of IT department with subordinates through qualitative criteria Tab. 4).}

Table 4 - Evaluation of criteria by Head of IT department

\begin{tabular}{|c|c|c|c|c|c|c|c|c|}
\hline \begin{tabular}{|l} 
Employee \\
identification
\end{tabular} & 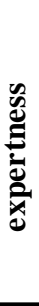 & 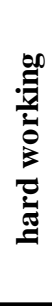 & 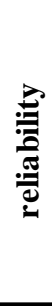 & 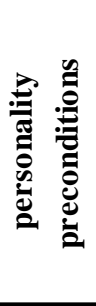 & 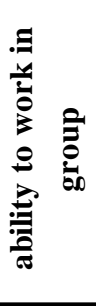 & 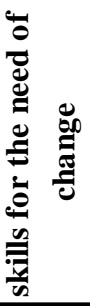 & 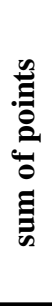 & Result \\
\hline I1 & 5 & 4 & 4 & 3 & 4 & 5 & 25 & IN \\
\hline I2 & 5 & 4 & 4 & 2 & 3 & 1 & 19 & OUT \\
\hline
\end{tabular}

The table shows that one employee gained evaluation higher than 20 points and on the contrary, one employee gained evaluation lower than 20. Head of IT department highly evaluates expertise, hard working and reliability of both employees. In the criterion of personality traits, just one employee gained threshold limit, the other one doesn't meet this criteria at all. Only one employee was evaluated as able to work in a group. Skills needed for the change implementation had only one employee. Head of IT department evaluates the rate of cooperation as excellent just with one employee.

Total evaluation classified one employee into in-group and one employee into out-group. 
e) Analysis of criteria evaluation of the relationship of Head of dispatch department with subordinates through qualitative criteria (Tab. 5).

Table 5 - Evaluation of criteria by Head of dispatch department

\begin{tabular}{|c|c|c|c|c|c|c|c|c|}
\hline \begin{tabular}{|l} 
Employee \\
identification
\end{tabular} & 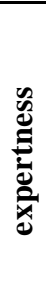 & 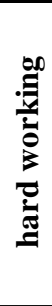 & 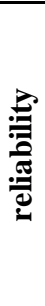 & 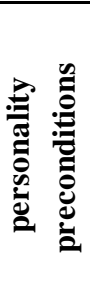 & 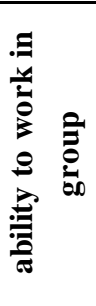 & 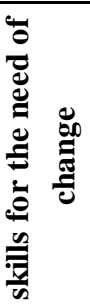 & 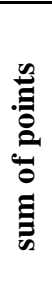 & Result \\
\hline E1 & 5 & 5 & 5 & 5 & 5 & 5 & 30 & IN \\
\hline E2 & 4 & 2 & 2 & 2 & 3 & 2 & 15 & OUT \\
\hline E3 & 5 & 5 & 5 & 5 & 5 & 5 & 30 & IN \\
\hline$\overline{E 4}$ & 4 & 5 & 4 & 4 & 4 & 4 & 25 & IN \\
\hline
\end{tabular}

The table shows that one employee gained evaluation lower than 20 points and three employees gained evaluation higher than 20. The Head of dispatch department highly evaluates expertise of all her employees. One employee gained insufficient evaluation in terms of hard working, reliability, personality traits and skills needed for change implementation. With three employees, she has evaluated her cooperation as very good. Head of dispatch department has evaluated her cooperation with one employee as insufficient.

Total evaluation classified one employee into out-group and three employees into in-group.

f) Analysis of criteria evaluation of the relationship of Head of operation department with subordinates through qualitative criteria (Tab. 6).

Table 6 - Evaluation of criteria by Head of operation department

\begin{tabular}{|c|c|c|c|c|c|c|c|c|}
\hline \begin{tabular}{|l} 
Employee \\
identification
\end{tabular} & 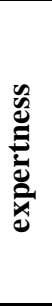 & 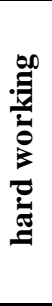 & 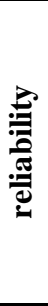 & 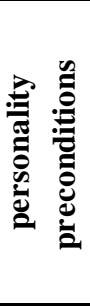 & 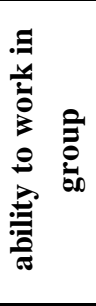 & 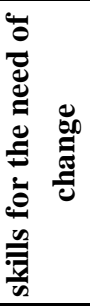 & 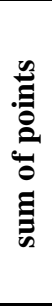 & Result \\
\hline P1 & 5 & 5 & 5 & 5 & 5 & 5 & 30 & IN \\
\hline P2 & 5 & 5 & 5 & 3 & 3 & 5 & 26 & IN \\
\hline P3 & 5 & 5 & 4 & 4 & 4 & 4 & 26 & IN \\
\hline P4 & 4 & 3 & 4 & 4 & 3 & 1 & 19 & OUT \\
\hline
\end{tabular}


The table shows that all but one employees gained evaluation higher than 20 points. Head of operation department highly evaluates expertise, hard working and reliability of his employees. One employee gained threshold limit in criterion of personality traits and ability to work in a group. One employee gained insufficient evaluation in a criterion of skills needed for change implementation. Head of operation department evaluatescooperation with his subordinates as very good.

Total evaluation classified three employees into in-group and one employee into out-group.

g) Analysis of criteria evaluation of the relationship of Head of warehouse no. 2 with subordinates through qualitative criteria (Tab. 7).

Table 7 - Evaluation of criteria by Head of warehouse no. 2

\begin{tabular}{|c|c|c|c|c|c|c|c|c|}
\hline \begin{tabular}{|l|} 
Employee \\
identification
\end{tabular} & 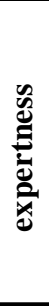 & 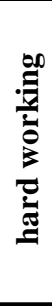 & 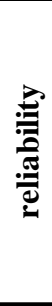 & :0 & 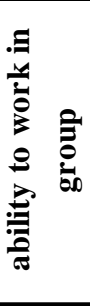 & 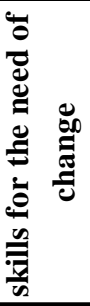 & 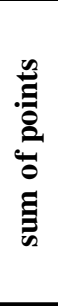 & Results \\
\hline S1 & 5 & 5 & 5 & 4 & 4 & 5 & 28 & IN \\
\hline S2 & 5 & 4 & 3 & 3 & 2 & 5 & 22 & IN \\
\hline S3 & 5 & 5 & 5 & 4 & 4 & 5 & 28 & IN \\
\hline S4 & 5 & 3 & 3 & 3 & 3 & 5 & 22 & IN \\
\hline
\end{tabular}

The table shows that all employees of warehouse no. 2 gained evaluation higher than 20 points.

Head of warehouse no. 2 highly evaluates expertise of all her employees. Three employees were evaluated as hard working, one employee gained threshold limit in this criterion. Two employees of warehouse no. 2 were evaluated as very reliable, two of them gained insufficient evaluation. Only two employees gained excellent evaluation in the criterion of personality traits and ability to work in a group. All employees of warehouse no. 2 have skills needed for the change implementation. We can say that the Head of warehouse no. 2 evaluates cooperation with her employees as good.

Total evaluation classified employees of warehouse no. 2 into in-group. 
h) Analysis of criteria evaluation of the relationship of Head of warehouse no. 3 with subordinates through qualitative criteria (Tab. 8).

Table 8 - Evaluation of criteria by Head of warehouse no. 3

\begin{tabular}{|c|c|c|c|c|c|c|c|c|}
\hline $\begin{array}{l}\text { Criterion } \\
\text { employee } \\
\text { identification }\end{array}$ & 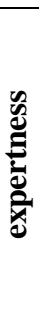 & 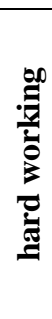 & 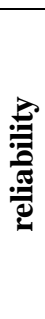 & 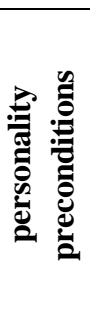 & 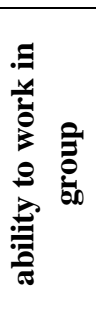 & 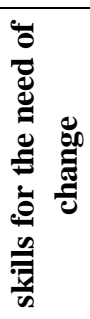 & 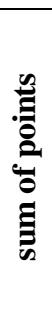 & Result \\
\hline S5 & 5 & 5 & 4 & 4 & 5 & 5 & 28 & IN \\
\hline S6 & 5 & 5 & 4 & 4 & 5 & 5 & 28 & IN \\
\hline S7 & 5 & 5 & 4 & 3 & 4 & 5 & 26 & IN \\
\hline S8 & 5 & 5 & 5 & 5 & 5 & 5 & 30 & IN \\
\hline
\end{tabular}

The table shows that all employees of warehouse no. 3 gained higher evaluation than 20 points.

Head of warehouse no. 3 highly evaluates expertise, hard working and reliability of all her employees. Three employees have very good personality 'traits, one employee reached threshold limit in this criterion. She has evaluated the ability to work in a group, as well as skills needed for the implementation of change as very good. Head of warehouse no. 3 evaluates cooperation with her employees as very good.

Total evaluation classified employees of warehouse no. 3 into in-group.

Based on evaluation, extend, up to which they meet qualitative criteria, divided employees into two groups:

1: "in-group" - employees, who meet qualitative criteria for the change implementation,

2: "out group" - employees who don't meet qualitative criteria for the change implementation.

The result of examination is basis for the set up of VDL model of LC SA a.s. 


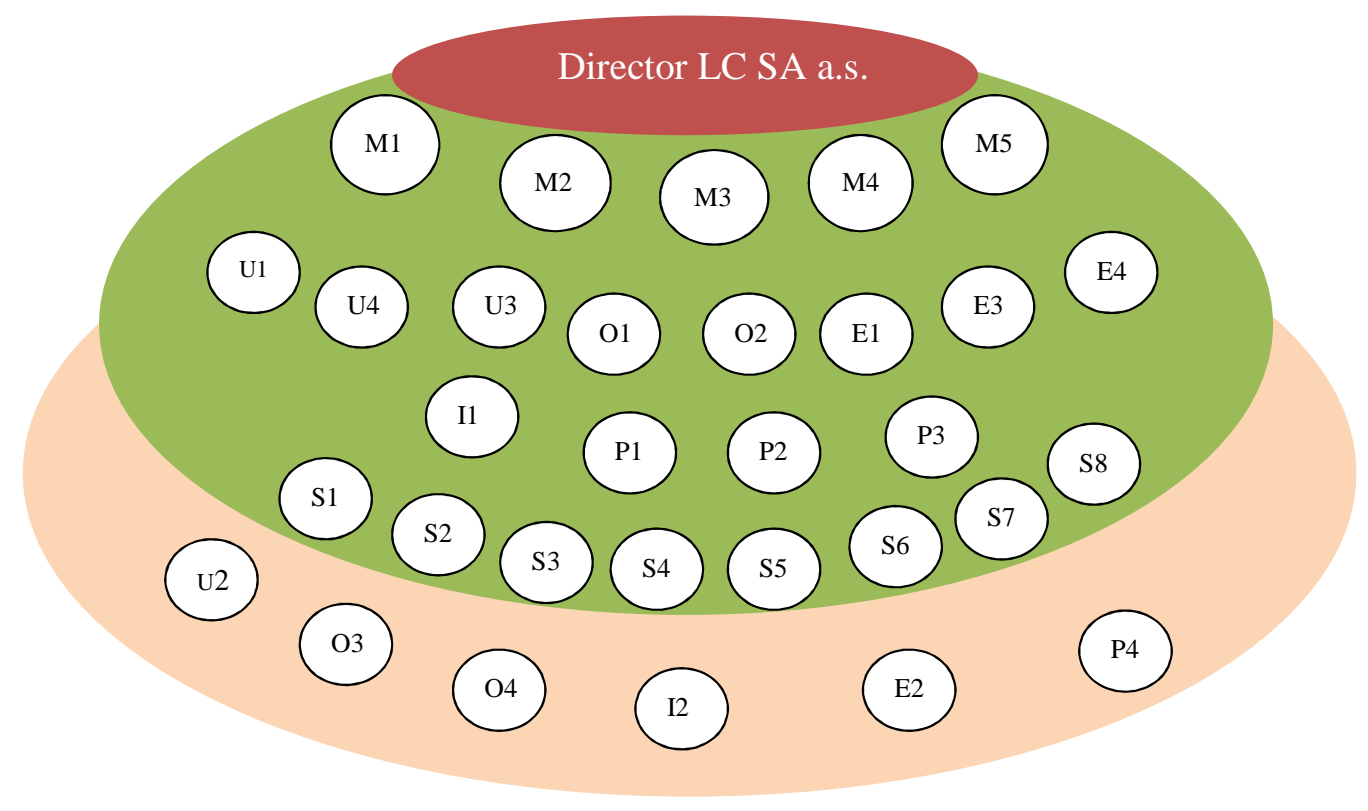

Figure 1-Model VDL LC SA a.s.

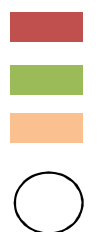

top manager - director of LC SA a. s.

in-group

out-group

employees' identification

M1, M2, M3, M4, M5 - managers on middle stage of management

$\mathrm{U} 1, \mathrm{U} 2, \mathrm{U} 3, \mathrm{U} 4$ - employees of financial department

I1, I2 - employees of IT department

$\mathrm{O} 1, \mathrm{O} 2, \mathrm{O} 3, \mathrm{O} 4$ - employees of sales department

E1, E2, E3, E4 - employees of dispatch department

P1, P2, P3, P4 - employees of operation department

S1, S2, S3, S4 - employees of warehouse no. 2

S5, S6, S7, S8 - employees of warehouse no. 3

From the VDL model it is clear that all managers of the middle stage of management and line managers are in the in-group. All employees of financial department are classified in the in-group. Two employees of the sales department are in the in-group and two of them are in the out-group. One employee of IT department is classified into in-group and one into out-group. One employee of dispatch department is classified into out-group, while three others are in the ingroup. Employees of operation department, warehouse no. 2 and warehouse no. 3 are all classified into in-group. 


\section{PREVIEW OF PERFORMANCES/OUTPUTS}

Since 2011, LC SA a.s. has experienced the results with growth. In the below mentioned overview there is an overview of outputs related to the period 2011 2013 on the basis of real data acquired from the accountings of LC SA a.s. For the estimation of results for 2014 we have used statistics method of forecasting (Tab. 9).

Table 9 - Overview of outputs of LC SAa.s.

\begin{tabular}{|c|c|c|c|c|c|}
\hline $\begin{array}{c}\text { Quarter } \\
\text { Year }\end{array}$ & $\begin{array}{c}\text { I.Q } \\
\text { (in EUR) }\end{array}$ & $\begin{array}{c}\text { II.Q } \\
\text { (in EUR) }\end{array}$ & $\begin{array}{c}\text { III.Q } \\
\text { (in EUR) }\end{array}$ & $\begin{array}{c}\text { IV.Q } \\
\text { (in EUR) }\end{array}$ & Total a year \\
\hline $\mathbf{2 0 1 1}$ & & & & 1835865 & 1835865 \\
\hline $\mathbf{2 0 1 2}$ & 5272043 & 5517528 & 5723700 & 5922144 & 22435415 \\
\hline $\mathbf{2 0 1 3}$ & 5372554 & 5498852 & 6090972 & 5928552 & 22890930 \\
\hline $\mathbf{2 0 1 4}$ & 5473065 & 5480176 & 6458244 & 5934960 & 23346445 \\
\hline
\end{tabular}

The details shows that wholesale turnover in the first, third and fourth quarter has had growing tendency annually. There was reported decreasing trend in the second quarter in years 2012 - 2013. We have tried to idenfy the reason. Based on data from accountings and discussion with the director, we have recognized that national holidays had a strong influence on a number of deliveries and thus on profits.

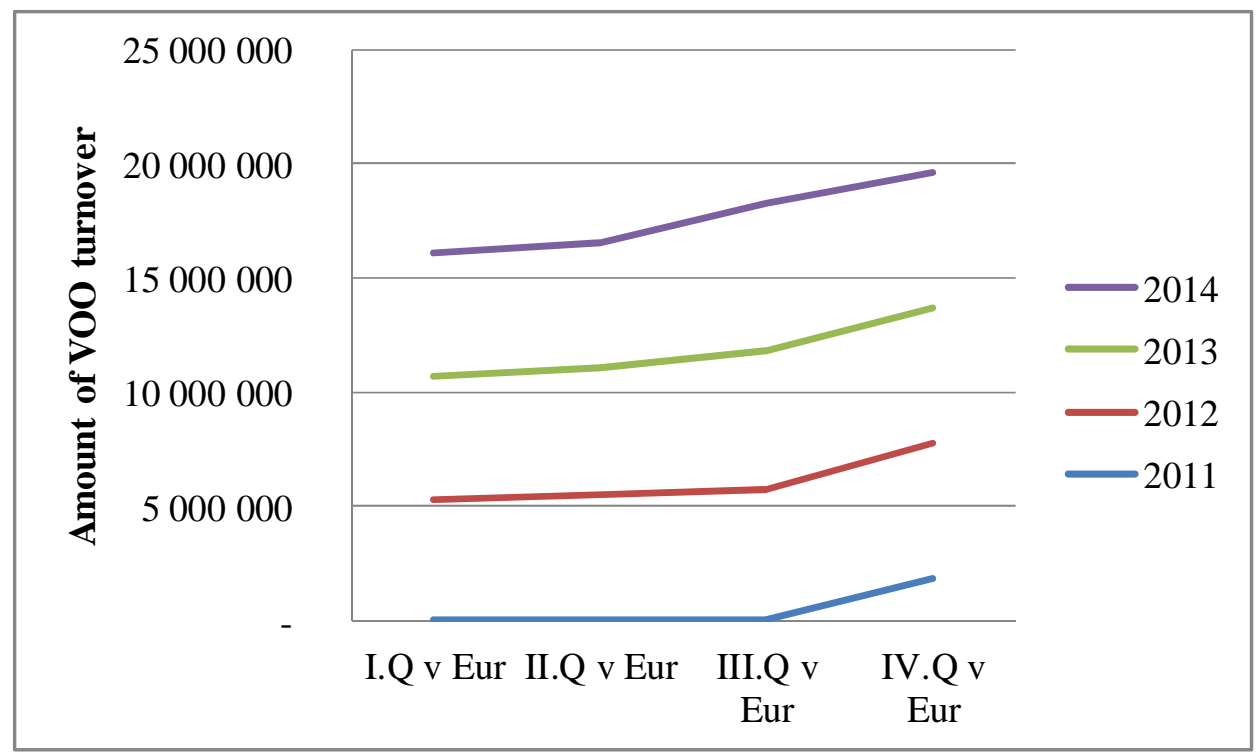

Graph 1 - Preview of outputs of LC SA a.s.

The graph shows that outputs during years 2011- 2013 had upward trend. Forecast for 2014 shows that outputs should grow also in the following period. 
Company records the highest growth annually in the third quarter, and the same is assumed also for year 2014.

\section{CONCLUSIONS FROM ANALYSES}

Based on the results of the situational analyses, set up VDL model and preview of outputs, we have come to the following conclusions.

The result of the situational analysis shows that since the organization establishment, it constantly expands its assortment volume, what causes problems with the capacity of goods storage. At the moment, the total amount of stored items in LC SA a.s. company is approximately 4000 pieces. With given amount of items and flow of goods, itis not possible to keep order, control and overview about all stock items. There are mistakes/errors and problems in goods location on stock. Organization solved the problem by building additional storage facilities for warehouse no. 1, what has solved the situation only for assortment group no. 1 and it has helped to move a part of assortment from warehouse no. 2 . At the moment, in warehouse no. 2 and warehouse no. 3 there are not a sufficient shelf positions for the given assortment and goods are placed in warehouse aisles. This causes problems with the goods preparation before their distribution. The situation complicates the work of warehouse employees, whereas the space for handling has been decreased. This prolongs the time for goods preparation, what affects adversely the work of dispatch department. The growing number of claims is also an unfavorable aspect for the organization, which is caused by incorrectly prepared goods. The result of situational analysis is the fact, that organization has insufficient amount of storage capacities due to constant expansion of assortment. Itis necessary to deal with this alarming situation by building additional new storage facilities.

VDL model has been used to set up the group of employees who will participate in implementation of innovation. In the first step, based on functional classification and functional scope of employment, we have eliminated from the analysis employees, who will not participate in the change implementation. Consequently, with the help of criteria, we have evaluated the relationship of superordinate and subordinates. The evaluation has been performed by the Head employees on all stages of management. For the evaluation, they have used defined scaling. The sum of values decided whether the employee would be classified into in-group or out-group. Employees who would participate in the implementation of innovation were classified into in-group, while employees evaluated by managers as those with whom they would not cooperate during the implementation of innovation were classified into out-group. Based on VDL model results, out of 31 evaluated employees, 26 were classified into in-group and 5 into out-group. 


\section{INNOVATION OF THE SYSTEM OF STORAGE POSITION AND LOCATIONS WITH THE USE OF IT}

Based on the need for storage premises innovation, a key proposal of innovation processes for goods preparation before their distribution was made.

The aim of the proposal is the change in the system of storage, what will improve the overview of location of individual stock items and make the process of goods preparation more efficient. The basis is the logic of arrangement of goods flows.

For the implementation of this proposal, it is necessary to select a supplier for the purchase of the shelf system that would allow definition of locations, so that the warehouse employee makes the shortest route possible.

The Head of economic and IT departments will be responsible for the collection of offers for the purchase of the shelves. The list of suppliers will be presented to board of directors by the director of LC Sabinov a. s., who will approve the selection of supplier for the purchase of shelves. After the delivery and installation of shelves, the goods from warehouse no. 2 and 3 will be moved into newly built storage facilities. It won't be possible to perform the process of goods preparation during goods displacing. The location of individual types of goods will be done by descending way. It does mean that warehouse employee starts the process of goods preparation with the goods of highest weight and ends the process of goods preparation with the most light one. For the arrangement of storage locations, it is necessary to collect information about dimensions and weights of individual goods. At the same time, it is necessary to define preparatory positions and rules for their refilling. Head of IT department in cooperation with Head of operation department will be responsible for the collection of these information.

Naturally, it will be necessary that employees of the warehouse adopt logic and new processes for goods preparation.

We have elaborated an alternative to internal warehouse arrangement. The solution is shelf system with sufficient area for manipulation for the work of warehouse employees. The maximum utilization of the floor area and preservation of comfort for warehouse employees and elimination of abundant moves at work, as well as utilization of information from the information system, which will determine the order of goods preparation before their distribution should be taken into account. The Head of IT department will prepare, in cooperation with software organization, implementation of this proposal, by specifying preconditions for the optimalization of goods preparation, what will represent another innovation in the examined organization. The contribution (of this article) could be defined in a practical level, namely in specification of proposals that were accepted by a given company and are being implemented now. Experience from implementation of innovation process will be a subject of other casually analyses for the future innovation processes. 


\section{CONCLUSION}

In very competitive business enviroment the constant innovative change never ends. In contrast to industrial era the innovative changes do not happen only in the field of technologies or economics but also in the consciousness and attitudes of people. One can not imagine innovation without people. In the process of innovative changes the organization should focus on positive atmosphere inside the organization. Here is very important the role of management. VDL model is not complicated. The whole employee selection process through VDL model is simple and is performed in general but the selection criteria are not defined. Procedure described in the article is an inspiration for managers to objectively assess/evaluate abilities of their employees needed for the implementation of innovation.

The main benefit taken from storage procedure improvement which we could expect here is mainly time saving and better goods preparation efficiency. The other benefits coming form stacking and better utilization of storage place will help us to keep place clean and will result to bringing the things under control. Another benefit coming from this proposal is decreasing number of failures. Also this should improve the goods searching process in the warehouse as well as eliminate the damage risk of the goods caused by unappropriate storage conditions.

\section{REFERENCES}

Bedrnová, E. and Nový, I., 1998. Psychologie a sociologie ř́zení. Praha : Management press, ISBN 80-85943-57-3.

Dansereau, F., 1995. A dyadic approach to leadership: Creating and nurturing this approach under fire under fire. Leadership Quarterly, 6(4), pp.479-490.

Dansereau, F., Graen, G. and Haga, W., 1975. A vertical dyad approach to leadership within formal organizations: A longitudinal investigation of the role making process. Organizational Behavior and Human Performance, 13(1), pp.46-78.

Droppa, M., Mikuš, P. and Lysá, L', 2004. Manažment zmien. Ružomberok : Edičné stredisko Pedagogickej fakulty, ISBN 80-8084-005-9.

Graen, G. and Schiemann, W., 1978. Leader-member agreement: A vertical dyad linkage approach. Journal of Applied Psychology, 63(2), pp.206-212.

Holková. A. and Horňák, F., 2003. Angažovanost' manažérov pri zapájaní jednotlivcov do procesu efektívneho zvládania zmeny ako podpora tvorivého prostredia podniku. Manažment v teórii a praxi, 3(2003) [online]. Available at: http://www.mtf.stuba.sk/docs/internetovy_casopis/2003/3/holkova.pdf [Accessed 28 February 2014] 
Liden, R. C. and Graen, G., 1980. Generalizability of the vertical dyad linkage model of leadership. Academy of Management Journal, 23(3), pp.451-465.

Majtán, Š., et al., 2012. Aktuálne problémy podnikovej sféry. Zborník vedeckých prác. Bratislava : Vydavatel'stvo Ekonóm, ISBN 978-80-225-3427-7.

Mikuš, P., 2010. Manažment zmien - konkurencieschopnost' organizácie. Ružomberok: VERBUM, ISBN 978-80-8084-561-2.

Robbins, S. P. And Coulter, M., 2004. Management. Praha: Grada Publishing, ISBN 80-247-0495-1.

\section{ABOUT THE AUTHOR}

Pavel Mikuš, Ing., Ph.D., Lecturer at University of Ružomberok, Faculty of Education, Department of Management, Nábrežie Jána Pavla II 15, 05801 Poprad, e-mail: pavel.mikus@ku.sk 